\title{
The Survival of the Yorùbá Healing Systems in the Modern Age
}

\author{
Ilesanmi Akanmidu Paul \\ Department of History and International Studies \\ Adekunle Ajasin University \\ Akiungba-Akoko, Nigeria \\ paul.akanmidu@gmail.com
}

\begin{abstract}
This study investigates the philosophy and tradition of the Yorùbá healing system and the reasons for its survival into the modern age. The introduction of western-style healthcare by missionaries-which became consolidated under colonial rule, from any point of view was attempted to stiffen the survival of the former. Intentionally or inadvertently, the Yorùbá healing system was derogatorily deemed primitive and unscientific because of its ritualistic aspects, which were severely condemned. The activities of missionaries in the context of proselytism and colonial governmental policies entailed copious attempts to stifle and do away with the Yorùbá healing system. This study uses historical analysis to synchronize the factors that helped the Yorùbá healing system to survive in a threatening milieu, namely the pressures of western ideology. The study concludes that despite efforts by the propagators of western ideology, the Yorùbá healing system is still a highly favored form of healthcare in Yorùbáland.
\end{abstract}

\section{Introduction}

The concept of healing systems in Yorùbáland has attracted the attention of several scholars. While this effort is highly commendable, it is also important to note that despite the large body of literature on the subject matter, there are still some contradictions in the postulations and arguments of several scholars on this aspect of Yorùbá history. There are aspects of Yorùbá healing system that have been veiled or obscured to many people up to the present that need to be unlocked intellectually. This study, therefore, clarifies some of the convoluted observations of some scholars who-per sheer 
lack of adequate information on this subject matter-have transmitted misconceptions, which were then passed from one generation to the next. While this may be considered a forgivable error for some extant scholars, who have arguably also committed such monumental errors because of their misguided informants, who themselves were unwilling to divulge the truth about their cultural heritage to those they perceived as alien to their historical heritage, this cannot be accepted in the case of local researchers who were not diligent enough to cross-check their findings before transmitting erroneous information. Thus, it is from this mindset that this study sheds light on Yorùbá healing systems, which several scholars have misconstrued. Effectively, this study portrays Yorùbá healing systems as an aspect of history that takes time and effort to grasp. Reasons for this are clear: first, most of the traditional information about the healing systems of Yorùbá is not readily available to the public, so as to preserve its sacredness. Secondly, the custodians of this information and their trainees are bound by an oath to keep certain tenets that are fundamental to observe in secrecy. Such information becomes inaccessible to those who are not directly connected to the vocation. Thirdly, most researchers are not patient enough when they conduct research on the fundamental aspects of Yorùbá healing systems. Partial information that is divulged to them by appendages of the main actors of this tradition is often not carefully examined, questioned, or explained.

\section{The Philosophy and Theories of Yorùbá People on Health and Healing}

The Yorùbá people are one of the most researched ethno-linguistic groups in Africa. Their historical origin, sociology, religious, and economic lives have been extensively examined by varying scholars such as, Johnson (1921), Abimbola (1965), Fadipe (1970), Falola (1991), Asiwaju (1976), Akinjogbin (1967), and Akintoye (2010). The Yorùbá inhabit the southwestern part of Nigeria, as well as part of eastern Benin. Boundaries imposed by different colonial powers account for the division of Yorùbáland into what is presently two different countries, which themselves have endured distinct colonial experiences. They have been in existence long before colonialism. The philosophy of the Yorùbá on health and healing cannot be divorced from Yorùbá tradition and belief, in this case the philosophy of natural epistemology and the spiritual ontology of man. The former maintains that the man's life is influenced by his environment. In other words, the environment where man lives has a way of influencing his health. In this case, the Yorùbá believe that people who live in dirty environments will have poor health. In this respect, the Yorùbá believe that consuming contaminated food and drinking bad water, to a large 
extent, affect man's health. Other things that are also encompassed in this philosophy are that man is prone to accidents in his environment, which also have the ability to affect his health. For instance, a man could fall down in the farm during the rainy season and break his leg; likewise he could be bitten by a snake in the forest. The philosophy of the Yorùbá on these issues centers on the fact that all these affect man's physical body. They also believe that physical ailments can be remedied through the application of physical elements found in his environment. They apply herbs, leaves, bird feathers, and other aquatic elements to bring about solutions to physical health challenges. With regards to spiritual ontology, the belief of the Yorùbá is complex. The cornerstone of this belief is that man exists in both the physical and spiritual worlds. The physical world entails all the physical things that are visible to the eyes. It includes his height, stature, outlook, and the ways in which he relates to his environment. On the other hand, they believe in the spiritual existence of man, which entails ontological dimensions of man. In this ontology, it is believed that man's life consists of three elements: the spirit (èmí), the soul (okàn), and the body (ara). These three elements are necessary for a man to be whole. While the body is under the control and influence of man, the soul and the spirit are metaphysically controlled and are not within the realm of the mortal. This largely explains why the Yorùbá people believe that destinies are pre-determined in the realms of the spirit before transformation into life. Also, according to their belief, whatever a man becomes in life is a function of what he has chosen in the spiritual realm. An İjálá chant goes as follows:

Bí orí bá ń da rokoroko láàmú

Yóo dà bii pé kò lè rook tẹgbẹ rẹ

İkà kì ífẹ ká rẹrù ká sọ

Bí orí bá ń da șodeṣode láàmú

Yòo dà bii pé kò leè pẹan tẹgbẹ rẹ

Àtàrí laláyànmọo, orí lẹléjọ́

Kò sóoșà tí ń bánií jà lệhin orí ẹni

Orí ẹni ní wí pé kó ye ni

Àkàndéomo o șeé fijàgbà ${ }^{1}$

If a farmer's head is against him

It will appear as if he cannot work like his colleagues

The wicked don't want one unburden his burden

If a hunter's head is against him, it will appear as if he cannot hunt like his colleagues

1 Babalola (1966). 
A man' head is his most intimate deity

There is no Òrìsà working against one except one's head

It is a man's head that decrees success for him

Àkàndé is a difficult child to earn by quarrel.

The Yorùbá worldview, each human being acquires a destiny prior to his birth, which entails crossing the threshold that divides existence in the "other world (ọrun) and existence in this world (ayé). However, after acquiring this destiny in ọrun, the individual is induced to forget the content of that destiny before crossing the threshold that transforms the individual into a corporeal being. Once in this world, the only way for an individual-ignorant of his or her fate-to gain knowledge of that destiny is through divination, in which it is believed that the witness of destiny (elérii-ipin) reveals aspects of the divine plan to the inquirer through a highly trained diviner (Payne 1992). This is captured in this epigram:

\author{
Àkúnlèyànè dá \\ Òn làdáyébá \\ A dáyétán ojú ń kán gbogbo wa \\ Șìgbọ́n ẹdá náà kò leè padà lo yan òmíràn \\ Àfi ètùtù ló kü ${ }^{2}$
}

What was chosen kneeling down

Is what we find on arrival in this world

On arrival in this world, we became too impatient

(too much in a hurry to achieve our potentials)

But it is impossible to go back and choose another,

To prevent the deterioration of things is the

only course of action left.

\title{
Yorùbá Perception of the Causes of Illnesses
}

Contrary to the European postulations of germ theory-that physiological and anatomical disorders are a result of the activities of germs and viruses in the body system, the Yorùbá people believe that illness can be caused by enemies (ọtá), which include witchcraft (àje), sorcery (osó), a god (òrisà), or ancestors (ẹbora). There are also natural illnesses (ááre) and hereditary diseases (àisàn idílé). There seems to be some overlapping content in the two philosophies, such as the belief in heredity. Both philosophies believe that illness could be hereditary. This forms a focal point in the classic studies by Erinoso

2 Dosumu(1949), cited in Morakinyo(1983). 
(1978), and Oke (1982), who classified the causes of illness in the Yorùbá perspective into three categories, namely: supernatural, preternatural, or mystical and natural causes. It is also believed that when gods inflict a person with a disease, such disease can only be treated by traditional healers, who will consult an oracle (ifá) to know the cause and appropriate cure. Curing such an illness requires the appeasing of the gods, usually by a diviner (babaláwo). In some cases, certain diseases were attributed to the anger of the gods, especially when taboos had been broken. ${ }^{3}$ Some people also linked this with the high incidence of infant mortality (àbikú). Some diseases were attributed to the evil machinations of certain people who seemed to bear certain grudges against some individuals.

Yorùbá people see the Universe as a single unit, which contains the unborn, the living, dead, ancestors and other deities (Erinoso and Oke 1994). Beings in the spiritual realms protect those who live according to the norms and values that regulate the society. They believe that transgression against the deities or gods result in illness sent directly by the spirit or through sorcerers and witches. This type of belief does not only exist among the Yorùbá people but other groups in Africa-for instance, the Luo in Kenya, the Amhara in Ethiopia, and the Zulu in South Africa-also share the same philosophy. ${ }^{45}$

Beside the above beliefs of the Yorùbá on the causes of illness, Odebiyi and Togonu-Bickersteth (1987) have discovered that diseases and misfortunes are sometimes associated with the actions of the parents, particularly illnesses that are congenital in nature. In this case, the infant suffers an illness that is not of his or her "doing." Morakinyo (1988) asserts that the various beliefs of the Yorùbá people on causes of illness are complex. Their beliefs are encapsulated in sentiments, which vary considerably from one group to another within the Yorùbá ethnic group. Zewi (1989) also notes the activities of witchcraft, sorcery, spirit and poison were noted as part of the causes of illness among the people. Ebigbo (1989) has also found that Yorùbá people believe that breaking the rules of the deity can sometimes lead to illness. Prince (1975) explains that the Yorùbá believe that lives exist in two worlds: material, and immaterial spirit worlds. The latter, he argued, reflects the real world. Whatever the nature of the cause of illness or disease, there are those that specialize in healing and curing in Yorùbá land. These people are called

3 Odebiyi (1980,111-115).

4 Pearce (1989); Raharjo and Corner (1990).

5 Several scholars have done extensive studies in this regard, whose efforts are worthy of mention, including: Simpson (1980); Odebiyi (1980, 1989); Odebiyi and Young (1983); Ekong (1982); Odebiyi and Togonu-Bickesteth (1987); Foster and Anderson (1978); Morley (1978); Seijas (1973); Foster (1976); Hallgren (1992); Last (1993); Jahoda (1966); and Valabrega (1962), among others. 
different names, such as diviner (babaláwo), medicine man (onișègùn), and herbalist (elégbogi).

Babaláwo is a diviner who is knowledgeable in esoteric knowledge and secrets. ${ }^{6} \mathrm{He}$ pries into human problems, events, the future, and causes of sicknesses etc. through divination. He makes use of an oracle (ifá) to find out the cause of ailments and how it could be cured especially when it appears to be spiritual problems. He often relies on sacrifices as remedy to ailments. On the other hand, the olóogùn or elégbogi an expert in herbal formulae. ${ }^{7} \mathrm{He}$ is wellversed and knowledgeable in herbal combinations that have the properties to cure ailments. There are two categories of ològùn or elégbogi in Yorùbáland. The first group specializes in medicine for adults, while the other group (eléwé omo) cares for children. However, there are some who combine the two functions, even though both are not often interested in ritual or incantations. ${ }^{8}$ This is a major point that differentiates between babaláwo and olóogùn or elégbogi. Commenting on this, Maclean wrote inter alia:

Although the latter are primarily concerned with treating bodily symptoms through the use of herbal remedies, while the former specialized in a form of psychotherapy for mental troubles and in disease due to supernatural influence or malevolence, in fact, they have much in common. Thus, a herbalist whose management of a case after prescribing several medicine has been unsuccessful, may resort to some simple divination procedures to clarify his diagnosis. On the other hand, a diviner is generally familiar with a large number of medicines of his own specialty. ${ }^{9}$

Another misconception that can be observed in the accounts of several scholars deals with the properties that are used in curing ailments and other diseases in the Yorùbá healing system. Many Eurocentric and some Afro-centric scholars have continued to use magic inclusively interchangeably with medicine. Field (1937) describes witchcraft as bad medicine directed destructively against other people, with no rites, ceremonies, incantation, or invocation that the witch has to perform connected to it. He defines a witch as a person who is the abode of an evil entity. At this juncture, we must distinguish between witchcraft and sorcery as duly applicable to the Yorùbá people. A sorcerer uses charms, incantation or invocations, spells and magic knowingly, and with premeditation. A witch performs no rite, utters no spell, and

\footnotetext{
6 Awolalu (1979, 86-98)

7 Dopamu $(1977,276)$.

8 Dopamu $(1979,2001)$.

9 Maclean $(1971,32)$.
} 
possesses no medicine. ${ }^{10} \mathrm{An}$ act of witchcraft is a psychic act. In their own contribution to our understanding of the distinction between sorcery and witchcraft, Middleton and Winter inform:

Witchcraft is part of an individual's being, a part of his innermost self, while sorcery is merely a technique which a person utilizes. Thus, in some societies, a person's witchcraft can operate at times without his being consciously aware of the fact that it is doing so. This can never be the case with sorcery; recourse to it must always be on a deliberate, consensus and voluntary basis. ${ }^{11}$

The above suggests that the sorcerer makes magic to kill, but a witch has an inherent and intangible power to harming others. While a witch projects her evil imagination directly from the mind, invisibly, without cursing or invoking, a sorcerer manipulates some tangible materials to carry out his illicit deeds. In the mental and social attitude of the Yorùbá (and of Africans in general), there is no belief more profoundly ingrained than that of the existence of witches (àjẹ). All strange diseases, accidents, untimely death, inability to gain promotion in office, failure in examinations and business enterprise, disappointment in love, barrenness in women, impotency in men, failure of crops-along with many other misfortunes-can be attributed to witchcraft (Awolalu 1979).

It is true and we cannot deny the fact that magic and medicine are closely related but their goals are always different. However, Awolalu suggests that it is only in theory and in consequence of their being related to nature and the supernatural that magic and medicine are related. ${ }^{12}$ Magic according to Yorùbá dictionary is a ritual performance or activity believed to influence human or natural events through accents to an external mystical force beyond the ordinary human sphere. The above definition suggests that magic is a practical affair. It is a human art which involves the manipulation of certain objects which are believed to have power to cause a supernatural being to produce or prevent a particular result considered not obtainable by natural means. It is regarded as a means of handling the forces of nature (subjecting them to man's will), safeguarding his welfare, and shaping his destiny. It must be understood that magic in Yorùbáland is non-therapeutic in nature. It caters to concerns that are not associated with disease or illnesses. ${ }^{13}$ By na-

10 Evans-Pritchard $(1937,9)$.

11 Middleton and Winter (1942, 96-116).

12 Awolalu (1979, 74-76).

13 Dopamu $(2003,44)$. 
ture, the Yorùbá people (and human beings in general), want victory, success, good luck, protection from dangers, good harvest, successful business, rain for better crop yields, protection against accidents, and protection against forces of evil, among others. These concerns are quite distinct from pathological or therapeutic conditions of human beings, and they are mainly dealt with by the use of magic. One can fully observe that the babaláwo knows that man as a creature knows he is limited in wisdom, understanding, and ability. $\mathrm{He}$ knows that he needs things that he cannot procure on his own. He is confronted with many problems in the world and he seeks aid to be able to cope with them. Man is thus convinced that there are supernatural resources in the universe for his benefit and that these resources can be obtained by two different means:

By appealing to the transcendental being to satisfy his needs and by devising a means of tapping the elemental forces which are already created in the universe by the Supreme Being, and which can be procured by those who have "know how." Based on the above, we can suggest that magic-in nature, and in practice-involves the use of coercion on the transcendental Being to accomplish things. No one can exert force on the Supreme Being. What magic does is to tap the resources that are already provided by the transcendental being for the use of mankind, which resources are known only to those who have the esoteric knowledge.

Medicine, on the other hand, is both therapeutic (for the treatment or curing of diseases) and prophylactic (intended to prevent disease). It is rather a substance used for treating diseases. We can say, it is a science of treating and understanding diseases. This probably justifies the reason an olóogùn-a practitioner of oògùn-in Yorùbáland does not concern himself only with the treatment of disease, but he also understands the nature and etiology of disease or illness before embarking on treatments. It is in view of this that Awolalu (1979) defines medicine as, "the traditional art and science of the prevention and cure of diseases. It is the use of natural substance to prevent, treat or cure diseases. It can also mean medicament used internally or externally.

Among the Yorùbá people, "magic" (idán) is used interchangeably among many people with "medicine" (oogùn, egbogi, or ișègùn). But this is only in theory and a consequence of their being related to nature and the supernatural. There are recognizable similarities between magic and medicine, which must have informed this common misconception. For both magic and medicine, people use herbs, leaves, roots, bark, stems, seeds, flowers, fruits, binds, sap (or juices of trees and plants), as well as various birds and their feathers, beaks, lizards, heads, feet, toes, bones, and additionally, various animals and their skins, bones, skulls, heads, quills, excretions, various reptiles such as lizards, snakes, iguanas, monitors, geckos, and chameleon, various insects such 
as butterflies, flies, wasps, beetles, crickets, ants, and bees, as well as other inanimate objects like sand, water, stone, sulphur, iron, steel, gunpowder, and honey. One can also employ salt, whisky, palm oil, palm wine, and other types of liquid (Dopamu 1992).

Also, the practices of magic and medicine have similar methods of preparation. This may be by grinding or pounding materials, by burning into ash, by boiling or squeezing into a concoction, and by cooking the ingredients as a soup, all of which are done in specific places and at particular times (Dopamu 2000). In some preparations, it might be necessary to perform certain rituals, observe certain taboos, or sacrifice certain animals, including birds. At times-during the process of preparation-an herbalist may be required to refrain from eating certain foods, and abstain from having sexual intercourse. At times, it may be required that the process of preparation takes place at a particular time and the herbalist be naked. Another similarity is that magic and medicines are used almost in the same way. This could be by drinking, eating, wearing, burying, hanging, rubbing or exposing, by washing the body with infusion or by putting an object under one's pillow or carrying in a pocket; by throwing it away after use; or by reciting incantations either after the preparation of the recipe or before using it.

More importantly, both magic and medicine are invariably related to religion in terms of rituals, taboos, divination, and the supernatural (Dopamu 2000). Divination, gods, and spiritual beings are connected with religionas well as magic and medicine-in Yorùbá medicine. Names of divination feature prominently in traditional Yorùbá religion. Indeed, magic and medicine are similar to religion in practice, to such an extent that certain magical and medical preparations are not efficacious without religion. Some even depend on divine intervention for the achievement of their goals. This informed why Buckley noted that Yorùbá medicine is inextricably intertwined with religion. ${ }^{14}$

Besides, once magic or medicine has been prepared into powder, soup, liquid or any other form, it is difficult for an observer to tell which is which. The inability to distinguish between magic and medicine once they have been prepared lends credence to the assumption that both are the same. But all the similarities above do not obscure the fact that they are distinguishable in many respects.

Witchcraft, on the other hand, is derived from the word "witch," which identifies a person who possesses supernatural powers in consequence of having formed a league with the devil or with evil spirits, and through this evil alliance and co-operation possess a craft which enables her to perform

14 Buckley $(1981,1)$. 
supernatural acts that, in most cases, are destructive in nature. ${ }^{15}$ Thus, in Yorùbáland, witches are seen as the personification of evil: innately wicked people who work to do harm against others. They are capable of their nefarious deeds through their possession of mysterious powers unknown and unavailable to ordinary people. Idowu describes it as, "human beings of very strong determined wills with diabolical bent; [they] are the veritably wicked ones who derive sadistic satisfaction from bringing misfortunes upon other people ${ }^{16}$

On the subject of incantation and its uses among the Yorùbá people, various scholars have done extensive studies. For instance, Dopamu (1977), Olabimtan (1971), Awolalu (1979), Ajayi (1997) agreed that incantations involve the chanting or uttering of words purported to have magical powers. Sometimes, the incantations accompany medicinal preparations that are carried in the form of a ring (òrùka), amulet (ifúnpá), girdle (ìgbàdí), small gourd (àdó), or needle (abẹreé). The chanting of these words, often esoteric, entails commands to the gods or transcendent forces to help solve problems that are beyond the imagination of mortals. Charms have mysterious powers that are not frequently used, but once they are uttered, could make one escape death, vanish in the face of an imminent danger, destroy enemies (or wild animals), stupefy thieves, or shorten a distance, etc. Men who know these incantations claim to be capable of escaping imminent danger and being transported to wherever they command the charm to take them. ${ }^{17}$

In the analyses above, effort has been made to explore the concepts of magic, medicine, witchcraft, sorcery, and incantation as applicable to the Yorùbá people. Western science has, however, scorned the ideas behind these phenomena as a means of bringing about good fortune, prosperity, or misfortune. Ordinarily, in the everyday experience of the Yorùbá people, there is nothing to suggest that these elements have the power to bring a person's wealth or misfortune. But, the incantation that accompanies a prescription sets it out clearly as a theory and shows that the items are a medium for the transmission of other information. ${ }^{18}$ The incantation contains the knowledge that the items have specific powers when used in magic. Buckley seems to express this idea better in writing, "by exploring the etiology of the names of the ingredients, the incantations are able to bring to light knowledge about the power of ingredients which would otherwise remain hidden. The incantation

15 Awolalu (1979, 79-91).

16 Idowu $(1973,63)$.

17 Dopamu $(1977,451)$.

18 Awolalu $(1979,43)$. 
shows the names of the ingredients as embodying facts about the properties of natural phenomena." 19

In the traditional Yorùbá healing system, no one individual possesses a monopoly on the knowledge of healing diseases. This explains why Paul argued that there are specialties in Yorùbá healing systems. ${ }^{20}$ There are those who specialize in handling diseases that are largely associated with children (eléwé-ọọ). One could deem the eléwé-ọmọ, in modern terms, as "indigenous pediatricians." They are versed in the application of therapeutics for diverse sicknesses that usually pose challenges to the health balance of children. Sicknesses such as measles, small pox, and chicken pox are cured through the use of therapeutics and concoctions prepared by the eléwé-omo. Other medicine men, and medicine women, also specialize in female-specific diseases and childbirth. These individuals could be referred to as "indigenous gynecologists," and midwives, respectively, as they manage female-specific sicknesses, issues related to pregnancy, and deliver babies. In addition, they also see to women's healthcare before, during, and after the delivery of babies. They work in conjunction with herbalists who prescribe the herbs, leaves, and roots that are medicinally valuable to pregnant women. They give inoculation to pregnant mothers in the form of tattoos on their bodies, in order to prevent certain danger before, during, and after birth. ${ }^{21}$ Other people specialize in setting broken bones. Those who are involved in any form of accident-either in the farm or at home-which results in the breaking of any part of the body, such as legs and hands, are handled by bonesetters, who employ a method commonly referred to as telepathy. In this case, an object is used to represent an injured person. For instance, the leg of a hen can be broken and treated instead of the leg of the injured person. As the leg of the hen heals, so too does the leg of the injured person.

\section{Interaction of the Yorùbá Healing System with Western Medicine}

The interaction of the Yorùbá healing with orthodox or biomedicine began in the middle of the nineteen century when missionaries first made contact with the Yorùbá people. Ajayi (1965) and Ayandele (1966) have given elaborate accounts of how the missionaries penetrated into Yorùbáland.

Attacks on the Yorùbá healing system began when the missionaries penetrated western Nigeria for missionary enterprises. As part of the efforts to consolidate their influence, schools were established, initially as an agent

19 Buckley $(1985,1)$.

20 Paul (2014 136-142)

21 Odebiyi and Ekong (1982); Omorodion (1993); Jegede (1994). 
of evangelization. Schram corroborates the work of Ajayi and Ayandele in submitting that the missionaries laid the foundation for western healthcare services in Nigeria ${ }^{22}$ As part of the "proof" of genuine conversion and proselytism, converts were mandated to make an open declaration of their new faith. Missionaries condemned the use of traditional medicine in its entirety, due to its therapeutic processes. They also warned their converts against the use of divinations, which were a common means for the Yorùbá people of diagnosing diseases believed to have been caused by metaphysical forces. Similarly, missionaries frowned at sacrifices to the gods. They condemned traditional immunization against poison and evil forces, as well as any kind of magical invocation or incantation. ${ }^{23}$ The wearing of traditional charms and amulets was also condemned. Pregnant women were discouraged from consulting traditional herbalists for care. Paul (2015) argues that part of the reason some missions originally established maternity hospitals and clinics was to reduce the use of traditional healers. Furthermore, missionary schools did not incorporate anything on the traditional healing system in their curricula. The implication of this development was that children were dislocated from their traditional heritage. Although western ideologies against certain inhumane practices in the Yorùbá healing system were commendable (such as the killing of twin babies, human rituals, etc.), the condemnation of the entire system was undoubtedly excessive.

In the same vein, the colonial administration that was eventually established disrupted the activities of the Yorùbá traditional healing system. Colonial policies were by no means favorable to the Yorùbá healing system. In the first instance, the government did not include the teaching of Yorùbá traditional healing system in the curricula of its schools. Washington-Weik (2009) reiterates that traditional healers who sought to practice were mandated to register with the colonial government. The requirements for registration were so stringent that only a few healers could fulfill them. The survival of traditional healing during this period was a result of the resiliency of healers to keep their profession alive. Oyebola affirms that traditional healers in Yorùbáland demonstrated unity of purpose by organizing themselves into various associations, which enabled them to resist the pressures against them from the colonial government. ${ }^{24}$ However, Olu (2016) demonstrates that the colonial government opposed the activities of the traditional healers to create a monopoly for itself. Because most of the drugs used in Nigeria were imported from the countries of colonial powers, it became obvious that the

22 Schram (1971, 19-21).

23 Paul $(2014,136)$.

24 Oyebola $(1980,23-34)$. 
policy of discrediting the potency of the traditional healers was to avoid competition or threats to their lucrative industry. However, the outbreak of the First World War broke this barrier and created a level playing field for the Yorùbá traditional healers in competing against the Europeans (Prince 1962). During the war, shipments of consignments from the metropolitan state were largely halted or reduced because of the security challenges of shipping in the Atlantic Ocean, as Britain, an active participant in the war, presumed that her ships could become a target of enemy forces. This anecdote accounts for how traditional medicine became lucrative as a result of the scarcity of western medicine.

By the end of the Second World War, traditional healers in Asia had made great strides and were clamoring for global recognition. The World Health Organization (WHO) granted approval to their effort and rebranded it as "alternative medicine" in 1947. Hyma and Ramesh note that the successful recognition and integration of indigenous health care services with western medicine in India, Korea, China, Indonesia, and Singapore motivated the campaign in many developing countries, including Nigeria. ${ }^{25}$ What perhaps served as the greatest advantage in this struggle for survival of traditional healers was that the campaign was wholeheartedly supported, accepted, and promoted by the World Health Organization (WHO 1978).

The WHO began to canvass for legislation in support of the official recognition of traditional healers globally, with the aim of expanding the scope of healthcare services to all people, irrespective of their social status. In line with this development, traditional Yorùbá health practitioners made bold efforts to embark on structural re-organization and repackaging. First, they changed their identity from one of "traditional medicine" to "alternative medicine." It is highly probable that the term "traditional," as they were formerly called, seemed more primitive, hence the need for a new term. This strategy became necessary in the face of a global age of modernization of culture, as it had the aim of gaining acceptance, as well as making it more interesting and attractive to people who were gradually imbibing new trends in modernism (Maclean, 1976). Furthermore, the high rate of poverty in Nigeria, including within Yorùbáland, further accounted for the survival of traditional medicine. Health care services were not administered freely by missions, nor government or private hospitals. Acquiring drugs was expensive and beyond the means of a large portion of the population, leaving them outside the coverage of Western healthcare services. According to Oke, traditional medicines were relatively cheaper, thus affordable and closer to the people. ${ }^{26}$ Ogunlola (2014)

25 Hyma and Ramesh (1991, 42-43).

26 Oke $(1995,23-25)$. 
argues that Western medicines do not have solutions to all health problems, especially in societies where people still believe in spiritual causes of diseases in the form of witchcraft and sorcery. The Yorùbá still believe that spiritual problems can only be cured with spiritual solutions. In this case, traditional healers, especially diviners (babaláwo) must be consulted on who applied the knowledge of divination, in order to offer solutions to such problems. ${ }^{27}$ This might require sacrificing specific animal to the gods. Considering the efforts of the indigenous practitioners and their possible successes in some Asiatic countries, such as India, China, and Singapore, the WHO, in 1976, canvassed and lobbied for the official recognition of traditional healthcare services, which entailed official recognition, acceptance, and integration of traditional medicines along with their Western counterparts. It also entailed incorporating the services provided by traditional medicines with those of Western medicine, without prejudice and for the benefit of all. ${ }^{28}$ The Nigerian government accepted this, while expressing its readiness for integration. As Tella remarked, "judging from close to a hundred years of promoting western medicine in Nigeria, its services are only available to between $25-30$ percent of Nigerian population leaving 70-75 percent to the care of traditional medicine." 29

To address this, the Nigerian Government has sought to facilitate the integration of traditional and Western medicine in Nigeria, which has not yet yielded any appreciable results.

\section{Reasons for the Survival of Yorùbá Healing Systems}

Despite the challenges and pressure against the Yorùbá healing system over the years (by the missionaries and later the colonial government), it is remarkable that the Yorùbá healing system has survived various phases of historical development. Ogaga (2015) noted that Yorùbá healing system is the largest means of healthcare delivery among the Yorùbá people of western Nigeria, despite the popularity of Western medicine. The reason for the survival of Yorùbá healing system despite modernity rests largely on their culture. The worldview of Taylor (1994) on culture seems to capture and reinforce the argument here in that he posits that culture is the complex whole, which includes knowledge, belief, art, moral laws, customs, and other capacities and habits acquired by man as a member of the society. The attachment of the Yorùbá people to their culture explains why the introduction of Islam and Christianity have not been able to detach them from their traditional observances and customs, which Taylor counts as part of culture. It is within this

27 Maclean (1979); Osunwole (1978).

28 Cais $(1988,521-522)$.

29 Tella $(1992,3)$. 
attachment that Washington-Weik (2009) argues that the resiliency of the Yorùbá healers during the period of colonialism allowed them to survive several health policies put in place by the colonial administration, which was not favorably disposed to the survival of the Yorùbá healing system. The claim of Mbiti (1969) that Africans are attached to their religion is one suggestion as to the reason for the survival of Yorùbá healing system. This to some extent explains why, despite the expansion of Islam and Christian missions across Yorùbáland, herbalists are still being patronized. An average Yorùbá person is inquisitive about his or her destiny. The babaláwo or herbalists do not just prescribe therapeutics, moreover, they pry into why certain thing-like sickness-occur and what could account for them. Olaoye (2003) reiterates this in highlighting the belief of the Yoruba that is evidenced when they say, "there is more to what happens to man than what meets the eyes (ișé kan ki i șé lásán). These are the further reasons the babaláwo usually pries into matters by consulting an oracle (ifá) to find out the cause of certain things. ${ }^{30} \mathrm{This}$ belief explains why people patronize the babaláwo.

Similarly, the Yorùbá healing system is ubiquitous, accessible, potable, flexible and inexpensive. As Paul (2012) explains, every family has its own herbalist - a father, mother, aunt, or uncle - who handles small illnesses. Every family head has a pot of concoction (àgé) in his bedroom, which he resorts to at the onset of any symptom of illness in any member of the family. This, to a large extent, serves as first aid in the modern age, as it is given to a sick person before the arrival of a medical doctor. Apart from this, medication is very cheap. Ojo (2016) emphasized that in the Yorùbá healing systems; emphasis has not been put on the benefits or gains accruable from medical prescriptions, as it has in western medicine. In this case, herbalists treat their patients irrespective of their social or financial status, administering medicines, and allowing sick people to use the medicine and return later to compensate the prescribe. Within this system, sick people are not obliged to pay for medicine, but rather to appreciate the prescriber with cash or in kind. In the Yorùbá healing system, treatment of disease or sicknesses must not be commercialized to the point of making financial gains of sick people, is believed that such scheme makes medicines lose their potency and power to heal. The reason behind this philosophy among the Yorùbá people is the fact that the God of wisdom and knowledge (Olódùmarè) has supreme power over everything in the universe and that he gives such wisdom and knowledge to whoever he wants (Idowu 1973). Misuse of such knowledge is believed to be punishable by God after earthly existence.

30 Abimbola (1965); Evans-Pritchard (1937). 
Moreover, the spirit of communalism-which envelops the social life of the Yorùbá people-has also contributed to the survival of the Yorùbá healing system. Yorùbá people believe that no one lives to himself alone, which accounts for the practice of an extended family system. The welfare of every member of the family is the responsibility of every member of the family. The chain of linear connection (filial bonds) makes it extremely difficult for patriarchal family unit to be indifferent to the plight of any of their kin. Based on this aspect of Yorùbá philosophy, herbalists are obliged to respect this bond to and lend help to whoever requires it at any point in time.

Poverty is another potent factor that has helped or assisted the survival of Yorùbá healing system, in that the high rate of poverty in Africa generally has made it absolutely impossible for a high percentage of Africa's people to obtain Western medication when they are sick (Paul 2015). Western healthcare is indeed expensive, and its delivery is slow.

One cannot overlook the fact that the Yorùbá healing system has been dynamic, as it has acknowledged the impact and effects of modernism and globalization. This could have informed Oguntola-Laguda, who maintains that the Yorùbá healing system has witnessed many changes, as well as developments, in recent times. ${ }^{31}$ The years of interactions of Yorùbá healing system with Western medicine has influenced its practices and operation, to a large extent. In the first instance, traditional medicines are now produced and packaged in tablets, sachets, and bottles, which in form resemble Western medicines. In some places, there are resident doctors who are experts in diagnosing ailments with high-tech medical instruments. A good example of this experience can be seen in Yem-Kem, a traditional healing shop in Lagos that has many branches across Nigeria. This development can be appreciated better when one looks at the way in which traditional healers use modern equipment to expand their ventures. For instance, in gynecology, antenatal, and maternity practice, ultra-sound scanning machines are used to determine the sex, position, and well-being of a developing fetus. Complications that may require surgery are referred to specialist hospitals for treatment.

Other reasons for their survival is the existence of metaphysical ailments that are not known or clear to Western medicine. The last resort for those who suffer such ailments is typically quick intervention by the traditional healers, especially the babaláwo. Examples of such health problems is a terrible sickness commonly contacted from women who engage in sexual relations with men other than their husbands (mágùn) which can neither be detected nor diagnosed scientifically, nor can science give remedy to the sufferer. Other ailments are spiritual in nature. These types of ailments cannot be detected

31 Oguntola-Laguda $(2015,118)$. 
by Western-style machines or laboratory examinations (Lambo 1969). The person affected by this type of incurable ailment languishes and suffers great pains, though laboratory tests and other methods of diagnosis confirm his or her health and do not provide evidence of impairment. Such ailments require the attention of diviners who pry into the realm of the metaphysical-through the instrumentality of their esoteric knowledge of nature-to correct the person's spiritual anomaly. People with these types of problems are advised by hospitals to try traditional methods.

The activities of Western healthcare services are popular in urban centers. Until the present, many rural areas have had no Western healthcare center. In such places, healthcare delivery consists completely of traditional methods. Itayvyar (1992) and the recent study carried out by Paul (2016) show that only 40 percent of the Yorùbá population lives in cities and urban centers. 60 percent of the Yorùbá population dwells in rural areas, such as plantation farms, hamlets, and villages, where there are no hospitals, maternity hospitals, or clinics. Healthcare is delivered in these places by means of traditional methods.

Apart from the above, the materials and the ingredients for medicines are simple, accessible, and most are easily prepared. Exceptions to this are in cases of complicated matters such as mental illness, barrenness, and sickle cell anemia, which require sacrifices and invocation of spirits. ${ }^{32} \mathrm{Common}$ ailments such as fever, cold, cough, malaria, jaundice, and body pains are cured through the elemental part of the medicine. Dopamu (2000) enumerated the various items used as common ingredients in Yorùbá healing system, and they are mentioned in the first part of this article. Most of these items are obtained easily, as they are available in the environment. Others can be acquired easily in the markets. Sellers usually display the items conspicuously for buyers to see them from a distance. Some of the items are grounded or mixed together for drinking, licking, or eating. Through this simple mechanism, within the family unit, healing is achieved. However, complicated matters are referred to the Yorùbá traditional herbalists: babaláwo, elégbogi, and olóogùn, among others, as the case may require intensive examination and prescriptions.

\section{Conclusion}

The Yorùbá healing system is blessed by the weight of history or practice over the ages. This traditional healing system affects every aspect of human healthcare, just like in the Western worldview. The Yorùbá are a religious people who also cannot be separated from their philosophy, beliefs, and tradition. It is this interconnectedness of their philosophy, tradition, and beliefs

32 Oshadare and Paul (2009, 228-229). 
that pitted them against the ideological perceptions of Western philosophy (Payne1992). Western healthcare ideologies frown at the principles that surround and govern the operation of the Yorùbá healing system. For instance, contrary to germ theory of disease in Western medicine, the Yorùbá believe in circular and spiritual theories. The latter aspect emphasizes sorcery (oșó), witches (àjẹ), ancestors, and transcendent forces among others, as possible causes of sicknesses and ailments. Similarly, in the Yorùbá healing system, sicknesses and ailments that are associated with spirituality are also handled spiritually. This sometimes involves sacrifices to the gods or invocation of spiritual forces through incantations that appeal to the gods for a cure. The obscurantism of the practices perhaps underscores the various epithets employed by the proponents of Western healthcare against the ancient system of the Yorùbá, such as the missionaries and exponents of colonial government who opposed the use of the Yorùbá healing system and deemed it as primitive and unhygienic. The missionaries condemned the whole process as idolatry and persuaded many converts to abandon the system. The consolidation of the British government and its policies favored the ideology of these missionaries. This development further aggravated the survival and challenges of the Yorùbá healing system. The government enacted several policies that were indisposed to the continued existence of the Yorùbá healing system. Despite the opposition of missionaries and the colonial government, the Yorùbá healing system has survived into the present. In the first instance, the Yorùbá traditional medical practitioners proved indefatigable, resilient, and focused. The inseparability of Yorùbá tradition and religion continues to make their healing system inevitable to even those that have been won over by Western philosophy. Yorùbá philosophy-which forbids profiteering from traditional healthcare delivery-makes these services affordable to everyone, irrespective of social status. The principles of accessibility, flexibility, and affordability have been major factors in its survival. This is coupled with the monopoly it still enjoys over certain spiritual problems, which are alien to and outside of the purview of Western medicine. The commonality of the Yorùbá healing system makes it universal in such a way that every family unit, household, and community has a basic knowledge of how to use the elements around them should health challenges arise. Despite the campaigns for Western-style healthcare and medicine in the modern times, the Yorùbá healing system remains the most patronized and largest medium of healthcare delivery in Yorùbáland.

\section{Works Cited}

Abímbola, W. Ifá: an exposition of the Ifa literary corpus. Ibadan: Oxford University Press, 1965. 
Awolalu, J.O. West African Traditional Religion, Onibonoje Press and Book Industry Nig. Ltd,

pp. 35-37, 1979.

Babalola, S. A. The content and form of Yorùbáìjálá, Oxford: Clarendon Press, 1966.

Buckley, A.D. Yorùbá Medicine. Oxford: Clarendon Press, 1985.

Cais, J. Integration of Traditional Chinese Medicine with Western Medicine-Right or Wrong in Science and Medicine 27, 1988.

Dopamu, P.A. Ofo: Yorùbá Incantations, Ibadan: Sefer Publications, 2001.

Dopamu, P.A. "Yorùbá Magic and Medicine and their Relevance for Today" Religion: Journal of the Nigerian Association for the Study of Religion 4 (1979):4f.

Ebigbo, P. O. "The Mind, the Body and Society: An African Perspective." In Clinical Psychology in Africa, eds.Peltzer and Ebigbo, 89-102. Enugu Working Group for African Psychology, 1989.

Erinoso, O. A. "Notes on concepts of disease and illness: the case of the Yorùbá in Nigeria." Nigeria Journal of Economic and SocialStudies 18.3 (1978).

Erinoso, O. A. and E. A. Oke. "Some basic concepts in medical sociology and anthropology.” In Sociology: Theory and Applied Malthouse Social Science Studies, ed. O. Otite. Lagos: Malthouse Press, 1994.

Evans-Pritchard, E.E. Witchcraft, Oracles and Magic among the Azande. Oxford: Oxford University Press, 1937.

Falola, T. Yorùbá Historiography, ed, Madison: University of Wisconsin, African Studies Program, 1991

Hyma, B and Ramesh, A. "Traditional Medicine: Its Extent and Potential for Incorporation into Modern National Health System" in Health and Development, eds. D.R. Philip and Y. Vergasselt, 42-43. London: Routeledge, 1991.

Idowu, E.B. African Traditional Religion, SCM Press Ltd, 1973.

Ihezue, U.H. The Influence of Socio-Cultural factors on Symptoms of depression Illness. In Peltzer,K\&Ebigbo, P.O.(Eds.) Clinical Psychology in Africa, eds. K. Peltzer \& P.O. Ebigbo, 217-223. Enugu; Working Group for African Psychology, 1989.

Itayvyar, D.A. "The Colonial Origin of Health Care Services: The Nigeria Example", in Political Economy of Health in Africa, eds. T. Falola, et al. Ohio: Ohio University Centre for International Studies, 1992.

Jahoda, G. "Supernatural Beliefs and Changing Cognitive Structures among Ghanaian University Students", Journal of Cross-cultural Psychology 1, (1966) $215-230$. 
Last, M. Non-western concepts of disease. In Companion Encyclopaedia of the History of Medicine, eds. W.F. Bynum, and R. Porter, 634-660. London: Routledge, 1993.

Maclean, U. Magical Medicine: A Nigerian Case Study, London: Allen Lane, 1971.

Mbiti, J. S. African Religions and Philosophy.London and New York: Heinemann, 1969.

Middleton, K and Winter, R. Soccery and Witzardry in African Context. ed, Oxford University Press, 1942.

Morakinyo, O. "The Yorùbá àyànmo, myth and mental health care." West Africa Journal of Cultures and Ideas, 1, no.1 (1983) 61-92.

Morley, P. "Culture and the Cognitive World of Traditional Medical Beliefs; Some Preliminary Considerations.” In Culture and Curing, eds. P. Morley\& R. Wallis London; Peter Owen Ltd, 1978.

Nzewi, E.N. Cultural factors in the classification of psychopathology in Ode, bíyi, A.I. Food Taboos in Maternal and Child Health; the views of traditional healers in Ilé-Ife, Nigeria. Social Science and Medicine, 28, (1989).

Odebiyi, A.I. and Togonu-Bickersteth, F. Concepts and Management of deafness in the Yorùbá Medical system: A case study of traditional healers in IleIfe, Nigeria, Lagos: Longman, 1987.

Ogaga, B.O. Personal interview, No. 17, Bello Street, Òsogbo, Nigeria, 2015.

Oguntola-Laguda, D. "Health, Healing, and Restoring" in African Indigenous Religious Traditions in Local and Global Contexts: Perspectives on Nigeria, a Festschrift in Honour of Jacob Olupona, ed. D.O. Ogungbile, 113-121. Lagos: Malthouse Press Ltd, 2015.

Oke, E.A. "Traditional Health Services: An Investigation of the Providers and the Level and Pattern of Utilizations among the Yorùbá", Ibadan: Ibadan Sociological Series no.1, 23-25 Department of Sociology, University of İbàdàn, (Nigeria), 1995.

Omorodion, F. The sociocultural context of health behaviour among Esan community, Edo State, Nigeria. Health Transition Review3 no. 2 (1993) 131-150.

Oshadare, O.T. and Paul, I.A. "Traditional Methods of Curing Mental Illness among the Owé People of Kogi State in Nigeria" in History of Indigenous Science and Technology, ed. R. A. Olaoye, 228-229. Ibadan: Cresthill Publishers, 2009.

Oyebola, D. D. "Traditional Medicine and Its Practitioners among the Yorùbá of Nigeria", Social Science and Medicine - Series A: Medical Sociology, London 24, no. 1 (1980) 23-29.

Pearce, T. O. "Social Organization and Psychosocial Factors Influencing Health Beliefs in South West, Nigeria." African Research Review Vol. 2, no.1 (1989) 197. 
Schram, R. A History of Nigerian Health Care Services, Ibadan: University of Ibadan Press, 1971.

Simpson, G.E. Yoruba Religion and Medicine in Ibadan. Ibadan University Press, 1980.

Tella, A. "Traditional/ Alternative Medicine in Quest of Health for All by the Year, 2000 AD.” An Inaugural Lecture Series, No. 51, University of Maiduguri, Nigeria, Maiduguri University Press, 1992. 